\title{
Sraffa and the Labour Theory of Value: a note
}

\author{
Sraffa e a teoria do valor-trabalho: uma nota
}

FABIO ANDERAOS DE ARAUJO*,**

\begin{abstract}
RESUMO: O autor procura demonstrar que o sistema de preços proposto por Piero Sraffa na sua obra Produção de Mercadorias por meio de Mercadorias - Prelúdio a uma crítica da Teoria Econômica é compatível com teoria do valor-trabalho incorporado de David Ricardo e de Karl Marx e com a teoria do valor-trabalho comandado de Adam Smith. Na realidade, a medida de preços de Sraffa, isto é, a Mercadoria-Padrão, satisfaz rigorosamente a condição matemática de invariabilidade em relação à distribuição de renda entre salários e lucros. Neste sentido, ela oferece uma solução consistente para o problema da transformação de valores-trabalho incorporado em preços de produção. Adicionalmente, a razão Padrão ou taxa máxima de lucros $\mathrm{R}$ pode ser usada na análise da evolução das três principais formas de progresso técnico na economia capitalista, a saber: intensivo em trabalho direto, neutro e intensivo em capital.
\end{abstract}

PALAVRAS-CHAVE: Valor-trabalho; preços, distribuição de renda; teoria econômica clássica e marxista; mercadoria-padrão; progresso técnico; renda; taxa de juros.

ABSTRACT: The author seeks to demonstrate that the price system proposed by Piero Sraffa in his major work Production of Commodities by Means of Commodities - Prelude to a Critique of Economic Theory is compatible with both David Ricardo and Karl Marx's labour embodied theory of value and with Adam Smith's labour-commanded theory of value. In reality, Sraffa's measure of prices, the Standard Commodity, satisfies rigorously the mathematical condition of invariability in relation to income distribution between wages and profits. In this sense, it offers a consistent solution to the transformation problem of embodied labour values into production prices. Besides, the Standard ratio or the maximum rate of profits $\mathrm{R}$ can be used to analyse the evolution of the three major types or forms of technical progress in a capitalist economy, as follows: labour-using, neutral and capital-using techniques.

KEYWORDS: Labour values; prices; income distribution; classical and Marxian economic theories; standard commodity; technical progress; rent; interest rate.

JEL Classification: B12; B51.

\footnotetext{
* Autonomous economic researcher, São Paulo/SP, Brazil. E-mail: fanderaos@gmail.com. ORCID ID 0000-0003-1910-489X. Submitted: 4/November/2017; Approved: 7/January/2019.

* The author is in debt with Professor Rodolfo Hoffmann, from both the University of Campinas and ESALQ/USP (Brazil) for his helpful comments and observations on the mathematical notation. However, errors that may remain are of my own responsibility.
} 


\section{INTRODUCTION}

The economic literature encompasses an endless number of articles, comments and warm discussions concerning the determination of prices from labour values, especially among the Marxian economists and those later known as Neo-Ricardians, whose magna opus is Piero Sraffa's Production of Commodities by Means of Commodities - Prelude to a Critic of Economic Theory published in 1960.

In this paper, we will demonstrate that the measure of prices and wages proposed by Sraffa, that is, the Standard Commodity, can be a consistent solution to the transformation problem of labour values into prices of production, because it satisfies rigorously the mathematical condition of invariability in relation to income distribution between wages and profits.

We will also show that there is a connection among the measures of value proposed by Smith, Marx and Sraffa. The construction of the Standard Commodity is rather closer to the measure proposed by Marx in Book III, chapter IX of Capital than to the average commodity imagined by Ricardo in the 3rd edition of his Principles, published in 1821.

Our major objective in this paper is not a reconciliation of Sraffa with Marx, but rather to show that the Sraffian model is not conflicting with the labour theory of value.

Worth mentioning that the labour theory of value has two major approaches, the labour-embodied theory of value of Ricardo and Marx and the Smith's labourcommanded theory of value. Sraffa was perfectly aware of the difference between these two approaches (see References to the Literature, Appendix D of his book) and his work, as we shall see, fits perfectly in these two approaches.

In order to clarify our exposition, it is worth mentioning a very important premise of the classical approach, including the Sraffian model, regarding the determination of values and prices.

Such premise is the previous knowledge of the physical output. In both Smith and Ricardo, as well as in the Sraffa's approach, the surplus is a magnitude independent on the determination of prices and distribution, contrary to the marginalist and neoclassical theories. In such theories, both prices and the output are simultaneously determined. In the classical theory instead, the production and distribution are two separate phases of the analysis and the adoption of the output as given is a preliminary approach to the determination of prices. The methods of production or the set of techniques are previously known by the capitalist and in this respect, there is no difference between the classical and neoclassical theories.

However, in the real world, the production level of a commodity may be affected by the relative prices of the means of production of such commodity. Although the classical economists knew about this aspect, it was not possible till now to establish a consistent relationship between prices and the quantities produced.

In the neoclassical theories, such connection is represented by both the demand curves and consumers' preferences. However, according to Garegnani (1984) in the neoclassical theories the demand is not a functional relationship between prices 
and quantities, but rather, a construction whose aim is to provide the distribution of income among the production factors, capital, labour and land.

\section{THE SINGLE LABOUR THEORY OF VALUE}

Adam Smith had noticed that, when the net income or surplus is fully absorbed by wages, the price of a commodity is exactly equal to its labour-embodied value.

This situation, however, only took place according to Adam Smith, 'in that early and rude state of society...' (The Wealth of Nations, $5^{\text {th }}$ edition, 1789, Book I, chapter VI).

Making use of the matrix notation, we can easily demonstrate the above Smiths dictum.

$$
\begin{aligned}
& \mathbf{v A}+\mathrm{L}=\mathbf{v B} \\
& \mathbf{v}(\mathrm{B}-\mathbf{A})=\mathrm{L} \\
& \mathbf{v}=\mathrm{L}(\mathrm{B}-\mathrm{A})^{-1}
\end{aligned}
$$

The determination of the absolute value of any commodity, expressed by the row vector of labour-embodied values (v), depends uniquely on the order $\mathrm{n}$ square matrix A regarding the quantities of means of production, on the diagonal output matrix $\mathrm{B}$ and on the row vector of the direct labour quantities $\mathrm{L}$.

There are $n$ independent equations and $n$ unknowns (v).

However, when we try to determine the prices of production, their solution is not as simple as above.

Besides the $\mathrm{n}$ prices, we have two additional unknowns, the distributive variables $\mathrm{r}$ and $\mathrm{w}$.

Such price system can be expressed as follows:

$\mathbf{p A}(\delta+\mathrm{r})+\mathrm{w} \mathbf{L}=\mathbf{p B}$

$\mathrm{A}=$ order $\mathrm{n}$ means of production square matrix

$\mathbf{B}=$ diagonal output matrix

$\mathrm{L}=$ row vector of direct labour quantities

$\mathrm{p}=$ price row vector

$\mathrm{r}=$ rate of profits (scalar)

$\delta=$ depreciation rate (scalar) and its value is between 0 and 1 .

When $\delta=0$ it means that the fixed asset has an infinite life expectancy, like land. There is no depreciation.

$\mathrm{w}=\mathrm{pb}$, the wage rate (scalar), where $\mathrm{b}$ is a column vector comprising a basket of consumption goods.

The means of production, represented by the square matrix A, correspond to the circulating capital, that is, they are fully consumed during the productive period. The fixed capital, comprised of machines and equipment, used up in the course of several production periods, was not included here, due to the need of a complex mathematical treatment. 
However, if we want to include the fixed capital in the above price system, it should be treated like we did with the circulating capital, that is, it will be entirely consumed in one production period, that is, the depreciation rate $\delta=1$.

The equation [2] is the Sraffa's price system expressed in matrix notation. As it can be noticed, such system operates in a competitive economy, given a uniform rate of profits.

The difference between the price system proposed by Sraffa and that proposed by Marx and other classical economists lies on the fact that the wages are paid post-factum, instead of a wage fund.

Alessandro Roncaglia (1984, chapter II, section 5, page 30), provides two political or ideological reasons.

Firstly, the wages will only be paid if the work had been fairly executed. Secondly, as an instrument of domination by capital over labour, causing the impression the capitalist pays exactly the amount for the quantity of labour dispensed in the production of commodities.

Firstly, let see the solution provided by Marx for the determination of prices of production in a competitive economy.

When the rate of profits is null $(\mathrm{r}=0)$ and the wages absorb all the national income, that is, $(\mathrm{w}=1)$, the above price system [2] is simply:

$$
\begin{aligned}
& \mathrm{pA}+\mathrm{L}=\mathrm{pB} \\
& \mathrm{p}(\mathrm{B}-\mathrm{A})=\mathrm{L} \\
& \mathrm{p}=\mathrm{L}(\mathrm{B}-\mathrm{A})^{-1}
\end{aligned}
$$

Therefore, in such case the prices are identical to their correspondent labourembodied values.

$$
\begin{aligned}
& \text { pi }=v i \\
& \text { and } \mathrm{i}=1,2, \ldots, \mathrm{n} \text {. }
\end{aligned}
$$

In a real capitalist economy, however, the rate of profits is positive. The wage rate, by its turn, is at least equal to the subsistence level or reproduction of the labour class. Since $\mathrm{w}$ and $\mathrm{r}$ are now unknowns, we need two additional independent equations to the determination of all prices, the wage and the rate of profits.

The Marxian price system can be expressed by the following set of equations:

$$
\begin{aligned}
& (\mathbf{p A}+\mathrm{wL})(1+\mathrm{r})=\mathrm{pB} \\
& \mathrm{w}=\mathbf{p b}
\end{aligned}
$$

In Book III, chapter IX, of Capital, Marx faced this problem by proposing firstly as standard of prices the equality between the surplus value (labour-embodied values) and the net output in terms of prices for the economy as a whole, given by the equation [5].

The above equation [5], necessary to the solution of the price system, shows simply that we cannot share or distribute more than was previously created by the society, expressed by the left side of the above identity. 
The simultaneous resolution of [3], [4] and [5] will determine the $\mathrm{n}$ prices and the rate of profits.

The real wage rate (equation 4) is exogenously given and comprises a basket of consumption goods previously defined (column vector b). The level of w depends both on the degree of political organisation of the labour unions and the historical standard of living of the labour class. Despite the wages in the Marxian system are included as means of production (wage fund), this fact does not change our conclusion on the subject.

Both Smith and Ricardo provided several reasons to support the adoption of a given real wage in the determination of prices. In Smith, the (nominal) wage is the result of a contract made between the master and the worker (bargaining) and he pointed out that it is not difficult to foresee which of the two parts take more advantage in the dispute. As the masters are fewer in number, they can combine more easily (The Wealth of Nations, chapter VIII, $\$ 12$ ). On the other hand, there are also acts and laws which prohibit the combinations among workers. In this sense, we may conclude that, for Smith, the situation was clearly unfavourable for the workers.

Besides this process of bargain, in the long term both the masters and workers depend on each other.

The result is that there is a minimum level for the real wage, defined as subsistence minimum. This level of subsistence should be sufficient to provide the sustenance of $\mathrm{n}$ the worker and his family. Smith also made a lot of other considerations about wages, comparing, for instance, the real wage in China and in England and concluded that is depends on historical and social conditions.

In Ricardo, the real wage is determined in the long run, that is, by the necessaries and conveniences required to support the reproduction of the labour class (Principles, Chapter V, On Wages). In such respect, Ricardo's analysis does not differ from Smith's. For Ricardo, the wages have a tendency to rise in real terms, due to the greater difficulty to produce "one of the principal commodities by which its natural price is regulated" (corn). However, as Ricardo recognises that "the improvements in agriculture, the discovery of new markets, whence provisions may be imported, may for a time counteract the tendency to a rise in the price of necessaries...” (Principles, Chapter V, On Wages, $\$ 3$ ).

Also, in Ricardo, as well as in Smith, there is a natural price and a market price for all commodities. "Labour, like all other things which are purchased and sold, and which may be increased or diminished in quantity, has its natural and its market price" (Principles, Chapter V, On Wages, $\$ 1$ ). By natural price Ricardo understands "the quantity of labour necessary to their production" (Principles, Chapter IV, On Natural and Market Price, $\$ 8$ ).

The market price of labour may deviate from the natural price and has its origin "from the natural operation of the proportion of the supply and demand" (Principles, Chapter V, On Wages, $\$ 5$ ), but such forces are temporary and not functional. In another passage, Ricardo states: "wages would fall, if they were regulated only by the supply and demand of labourers; but we must not forget, that wages 
are also regulated by the prices of the commodities on which they are expended" (Principles, Chapter V, On Wages, $\$ 25$ ).

These excerpts from Ricardo are a clear position of the classical approach that the conditions of production (labour and technology) play an important role in the determination of the real wage.

On the other hand, the level of the rate of profits expressed in labour value terms $\left(\mathrm{r}^{*}\right)$ is determined as follows:

$$
\begin{aligned}
& r^{*} \mathbf{v A}=\mathbf{v}(\mathbf{B}-\mathbf{A})-\mathrm{w}^{*} \mathrm{~L} \\
& \mathrm{w}^{*}=\mathbf{v b}
\end{aligned}
$$

In order to obtain $\mathrm{r}^{*}$ as a ratio (scalar), all the elements of both sides of the relation [6] are multiplied by a column vector $\mathbf{H}$ ( $n$ rows and one column, with all elements equal to 1$)$;

$$
[\mathbf{v}(\mathbf{B}-\mathbf{A}) \mathrm{H}-\mathrm{wLH}] / \mathrm{vAH}=\mathrm{r}^{*}
$$

$\mathbf{v A}=$ the value of capital employed

$\mathrm{w}^{*}=$ wage (scalar) in labour value terms $(0 \leq \mathrm{w} \leq 1)$

$\mathbf{v}(\mathbf{B}-\mathbf{A})-\mathrm{Lw}=$ total profits in labour value terms

$\mathrm{H}=$ column vector with all elements equal to 1 , that is, $n$ rows and one column

However, contrary to Marx's expectation, the above rate of profits $r^{*}$ is numerically different from that rate $(r)$ obtained from the simultaneous resolution of the price system (equations [3], [4] and [5]).

In other words, if we eliminate the identity given by equation [5] on page 4 and substitute the rate of profits in the system of equations [3] by the value of $r^{*}$, previously determined by the above relation [6], the relative prices in each industry will be different, which is contrary to the principle of a unique relative price structure.

On the other hand, if we adopt only one relative price structure for all industries, the rate of profits will have to be different in each industry, which is also inconsistent with the free competition assumption.

Therefore, we got into a crucial point of the Marxian transformation problem and such inconsistency is the reason by which Marx introduced another postulate of invariance, namely, total output equals total value, that is, $\mathrm{pB}=\mathrm{vB}$. From Marx's own words: "And in the same way the sum of the prices of production of all commodities produced in society - the totality of all branches of production - is equal to the sum of their values" (Marx's Capital, Book III, Part II, chapter IX).

However, the simultaneous adoption by Marx of the two measures of value does not provide a unique solution for the determination of commodity prices, as demonstrated by Francis Seton (1957) in his classic article. Therefore, the Marxian transformation of values into production prices remains without a satisfactory solution.

Worth mentioning that, due to a response to Eugen von Böhm-Bawerk, who in 1896 criticised the logical consistence of Marx'solution, several Marxian economists since Ladislaus von Bortkiewicz provided alternative postulates of invariance. I suggest the reader to examine three major articles on the subject, written by Kenneth May (1948), Joseph Winternitz (1948) and Ronald Meek (1956). 
Despite their efforts to preserve the basic structure of the Marxian transformation problem, none of such proposals can be accepted, because two limitations arise.

The first one regards the formulation of the problem. In general, the economic system is divided into few sectors, linked to the social classes for which the production is destined. The commodities are classified in terms of aggregates, such as capital goods, labour consumer goods and luxury goods.

The above limitation disappears by splitting the sectors into several industries, each one producing one single commodity. However, the Marxian economists faced a second difficulty, more complex, concerning the adoption of a postulate of invariance. The arguments proposed in favour of the postulates of invariance were in general subjective and quite difficult to be empirically confirmed. Ronald Meek, for instance, adopted the premise that the organic composition of capital in the sector which produces the necessary goods for the reproduction of the labour class is identical to the average organic composition of capital of the economic system as whole. Such premise is equivalent to say that the prices in that sector are equal to their correspondent labour values and Meek was unable to provide a logical explanation for his choice.

Although highly unfeasible, another situation by which the relative prices are equal to their relative values is when the organic composition of capital, expressed in labour-embodied values, is the same in all industries:

$$
\begin{aligned}
& \mathbf{v A}_{1}+\mathrm{L}_{1}=\mathrm{v}_{1} \\
& \mathbf{v A}_{2}+\mathrm{L}_{2}=\mathrm{v}_{2} \\
& \ldots \ldots \ldots \cdots \\
& \mathbf{v A}_{\mathrm{n}}+\mathrm{L}_{\mathrm{n}}=\mathrm{v}_{\mathrm{n}} \\
& \text { in which: }
\end{aligned}
$$

$$
\left(\mathbf{v A}_{1} / \mathrm{L}_{1}\right)=\left(\mathbf{v A}_{2} / \mathrm{L}_{2}\right)=\ldots=\left(\mathbf{v A}_{\mathrm{n}} / \mathrm{L}_{\mathrm{n}}\right)
$$

Let us see now the general case of an economy with two industries $(\mathrm{n}=2)$ and with the same proportion of indirect to direct labour:

$$
\left(\mathrm{a}_{11} \mathrm{v}_{1}+\mathrm{a}_{21} \mathrm{v}_{2}\right) / \mathrm{L}_{1}=\left(\mathrm{a}_{12} \mathrm{v}_{1}+\mathrm{a}_{22} \mathrm{v}_{2}\right) / \mathrm{L}_{2}
$$

Isolating the technical coefficients from values, we have:

$$
\mathrm{v}_{1} / \mathrm{v}_{2}=\left(\mathrm{a}_{22} \mathrm{~L}_{1}-\mathrm{a}_{21} \mathrm{~L}_{2}\right) /\left(\mathrm{a}_{11} \mathrm{~L} 2-\mathrm{a}_{12} \mathrm{~L}_{1}\right)
$$

The determination of the relative value of the commodity 1 to commodity 2 depends only on the given technical coefficients of production in each industry.

Since that proportion (expression [8]) is the same in each industry, the above result also applies to the price system:

$$
\begin{aligned}
& \left(\mathrm{a}_{11} \mathrm{p}_{1}+\mathrm{a}_{21} \mathrm{p}_{2}\right) / \mathrm{L}_{1}=\left(\mathrm{a}_{12} \mathrm{p}_{1}+\mathrm{a}_{22} \mathrm{p}_{2}\right) / \mathrm{L}_{2} \\
& \mathrm{p}_{1} / \mathrm{p}_{2}=\left(\mathrm{a}_{22} \mathrm{~L}_{1}-\mathrm{a}_{21} \mathrm{~L}_{2}\right) /\left(\mathrm{a}_{11} \mathrm{~L} 2-\mathrm{a}_{12} \mathrm{~L}_{1}\right)
\end{aligned}
$$

Therefore,

$$
\mathrm{v}_{1} / \mathrm{v}_{2}=\mathrm{p}_{1} / \mathrm{p}_{2}
$$

The ratio [8] is also known as the organic composition of capital and there are some basic reasons by which it is not equal in all industries. Some commodities, in 
order to be produced, demand a higher proportion of direct labour in relation to indirect labour (labour intensive techniques or labour-using techniques), for instance, fine leather consumer products and mechanical watches with several complications. On the opposite side, commodities such as steel, pulp \& paper and petrochemicals, for example, demand higher proportion of indirect labour (capital intensive techniques or capital-using techniques). Although we have a dominant production technique in each industry, depending on specific market conditions, the firms may also use alternative production techniques in order to both increase profits and to offer products according to their target-consumer preferences. Therefore, in the real world it is quite reasonable to suppose the existence of different direct labour to indirect labour ratios.

In the next section, we will demonstrate that the Sraffa's Standard Commodity is analogue to the first standard of prices proposed by Marx (equation [5]).

We also believe that both Marx and Sraffa adopted the surplus value as a major reference of prices because it is the most important economic magnitude in any economy and, in order to be consistent with the labour theory of value, the net income should be equal to the total quantity of labour spent during the production period.

\section{SRAFFA'S STANDARD COMMODITY}

The choice of the Standard Commodity as the numéraire of prices is a fundamental condition for the existence of a linear relationship between the wage and the rate of profits. This linearity, in its turn, is necessary to attend the mathematical condition of an invariable standard of value in relation to the distribution of the net income.

Sraffa was really concerned about finding an invariable standard for prices and wages in order to obtain a uniform rate of profits consistent with the concept of value. In other words, the rise of income share by one class should be exactly offset by the reduction of income share by the other social class.

The above mathematical condition we have referred to can be described as the first derivative of profits in relation to wages. This expression should be equal to -1 because any rise (or reduction) of total profits should be exactly offset by a reduction (or rise) of total wages. In this sense, we have:

$$
\begin{aligned}
& \mathrm{d}(\text { Profits })=-\mathrm{d}(\text { Wages }) \\
& \mathrm{d} \text { (Profits)/d(Wages) }=-1
\end{aligned}
$$

Sraffa obtained the following linear relationship between the rate of profits and the wage rate:

$$
\mathrm{r}=\mathrm{R}(1-\mathrm{w})
$$

It is worth mentioning the above relation (see Appendix I for a detailed construction of the Standard Commodity) apparently does not depend on the size of the surplus or on the absolute value of income. 
With the use of multipliers (column vector $\mathrm{Q}$ ), the net income of the real economic system is modified in order to reflect a uniform proportion between surplus and means of production and it becomes the invariable standard of prices and wages (equation [6 A] in the Appendix I).

Besides, by adopting the whole surplus value and its equivalent, the total quantity of labour utilised during the production period, as the standard of prices and wages, Sraffa avoids the subjectivity presented in the postulates of invariance proposed by Marx and other economists.

Since $\mathrm{w}$ is the share of net income that goes to wages, $(1-\mathrm{w})$ or $\mathrm{r} / \mathrm{R}$ represents the fraction of net income destined for profits. Thus, it is easy to demonstrate how the Standard Commodity or its equivalent equation [6 A] (Appendix I), fully attends the mathematical condition mentioned above.

Calculating the first derivative of the rate of profits in relation to the wage rate in the equation [9], we have:

$$
\mathrm{d}(\mathrm{r} / \mathrm{R}) / \mathrm{d}(\mathrm{w})=-1
$$

The standard of value proposed by Sraffa also eliminates the tautological reasoning in Adam Smith's labour commanded conception (The Wealth of Nations, $5^{\text {th }}$ edition, 1789, Book I, chapter V), since the relation [9] can also be written as:

$$
(1 / \mathrm{w})=\mathrm{R} /(\mathrm{R}-\mathrm{r})
$$

As $r$ goes to its maximum $R$, the lower will be the wage and, therefore, the higher will be the quantity of labour which the capitalist is able to buy or command. In other words, the notion of labour commanded in Smith has now an accurate meaning.

In the work of Smith, the value of any commodity is explained by the quantity of labour it can buy or command. However, such result depends on the level of the money wage in the labour market. As the wage comprises a basket of consumption goods, firstly we have to know previously the value of each of such commodities in order to explain the value of these same commodities. Therefore, we fell into a circular reasoning, which does not happen with the equation [9a] above.

The original price system (equation [2]) contains $n+2$ unknowns and $n$ equations. In order to determine the price of commodities, we need two more independent equations.

The $(\mathrm{n}+1)^{\text {th }}$ equation must be the standard of prices and wages. As there is a straight link between the Standard Commodity (equation [6 A] of the Appendix I) and the relation [9], the result will be the same if we use one or another as such standard. The linear relation, equation [9], has the advantage of being simpler and elegant, allowing a crystal-clear perception of the income distribution movements.

The $(\mathrm{n}+2)^{\text {th }}$ independent equation must reflect the value of one of the two distributive variables, by fixing the value of the wage or the rate of profits. Sraffa himself suggested the rate of profits as the exogenous variable in the price system and it is obtained as a function of the money rate of interest (Sraffa, 1960, chapter $\mathrm{V}$, section 44, page 33). 
Sraffa called money rate of interest because there is another type of interest rate, namely, the own rate of interest.

The concept of own rate of interest was idealized by Sraffa in 1932, but was Lord Keynes who provided its accurate meaning in the chapter 17 of The General Theory of Employment, Interest and Money (1937). In Keynes's words: “[...] for every durable commodity there is a rate of interest in terms of itself, [...]" and "[...] 100 quarters of wheat for spot delivery will buy 98 quarters for forward delivery, it follows that the wheat-rate of interest is minus 2 per cent per annum.”

For a full and clear explanation of the subject, I suggest the reading of the excellent essay Keynes and Sraffa on the concept of commodity rate of interest from Nerio Naldi (2012).

The money rate of interest is fixed by the monetary authority and its level depends on the objective of the Central Bank. Such objective may be, for instance, the control of inflation provoked by a faster economic growth or to stimulate the consumption of goods and services in the economy.

The level of the rate of profits is the sum of the money interest rate (i) fixed by the monetary authority with a risk premium, both in annual terms, that is,

$\pi=\mathrm{i}+\sigma$

where $\sigma$ is the risk premium, a pure number in order to offset the uncertainty. A priori the money invested in government bonds has no risk.

The overall risk premium $\sigma$ is the sum of five other independent types of risk, as follow:

- business risk

- financial risk

- liquidity risk

- exchange-rate risk

- country-specific risk

The level of the risk premium is different among industries. Each industry faces different types of uncertainty during the period of production. As a consequence, the rate of profits in one industry may be higher or lower in relation to the general or average rate of profits.

How each industry calculates each of the five above types of risk in order to determine the overall risk-premium $\sigma$ is a complex question to be answered in another occasion. It is not also a surprise if such calculus is really taking into account by the majority of companies and industries in their day-to-day running of their business.

In this sense, the hypothesis of free competition among industries must be abandoned, unless for didactic purposes we adopt the same risk premium rate $(\sigma)$ in all industries.

Once the rate of profits in fixed outside de system of production, the wage will be a residue, because the value of $\mathrm{R}$, the maximum rate of profits, is determined inside the production system, that is, by the conditions of production, regardless the determination of prices and distribution of income between wages and profits. 
In the classical economics the salary is treated as a given endogenous data and the rate of profits the residual. Sraffa, on the contrary, considers the profit rate as an independent variable.

Luiz Carlos Bresser-Pereira in his book Lucro, Acumulação e Crise (Profit, Accumulation and Crisis, 1986, see References) noted the rate of profits remained practically at a constant level since the last quartile of XIX century. Historically, the capitalists were able to stablish in the economic calculus a level for the rate of profits they consider appropriate. The wage rate, like Sraffa, is the dependent variable, as a result of the difference between surplus and total profits. I suggest the reading of the essay Distribuição de renda e o modelo clássico (Income distribution and the classical model, 2004, see References), which provides an analysis of both approaches in relation to the distribution of income.

There is no doubt that the Standard Commodity is a commodity ad hoc, built with a specific purpose, as Claudio Napoleoni pointed out (1973, page 243).

Although the Standard Commodity is a purely mathematical construction, it rigorously solves strictu sensu the problem of the net income distribution between wages and profits.

In Sraffa's book, contrary to Marx's Capital, there are no political or social concerns. His model is restricted to the quantitative aspects of distribution. For instance, when $\mathrm{w}=3 / 4$, it means simply that the wages account for $75 \%$ of the national income.

However, the real wage, constituted by a bundle of commodities, previously determined, has nothing to do with the Sraffa's Standard Commodity. It is highly possible that the physical composition of the real wage will not coincide exactly with the composition of the salary in terms of the Standard Commodity.

The Standard Commodity has the property to show that the Ricardo's corn-corn model "is hidden in any productive system" as pointed out by Marco Lippi (1998). The Standard Commodity is an elegant and pedagogical tool to understand the inverse relationship between the wage and the rate of profits. If any commodity or other composite commodity is used to measure prices and wages, we will not have a straight line between the two distributive variables. In other words, a reduction in total profits will not be immediately compensated by an increase in total wages.

\section{THE REDUCTION OF A PRICE INTO DATED QUANTITIES OF LABOUR}

The relationship between the price theory formulated by Sraffa and the labour theory of value becomes clearer with the method Reduction to Dated Quantities of Labour, presented in the sixth chapter of his book.

The method Reduction has its origins in the work of Ricardo - The Principles of Political Economy and Taxation - chapter I, section III, $3^{\text {rd }}$ edition, 1821) and also in the book of the Russian economist Vladimir Karpovich Dmitriev (18681913) - Economic Essays on Value, Competition and Utility, (Cambridge University Press, 1981, Domenico Mario Nuti - editor), originally published in 1902. 
The Reduction method shows that the price of a commodity is the result of a sum of labour quantities weighted by a profit factor, taking also into account the dates or rounds of production.

Although the understanding of the aggregation process of direct labour quantities is quite easy, a formal demonstration of the Reduction method is relatively complex, so that we will present only a concise exposition of it.

In order to make our explanation easier, let us use the Sraffa own mathematical notation for the price equation of the commodity $a$, as such:

$$
\left(\mathrm{A}_{\mathrm{a}} \mathrm{p}_{\mathrm{a}}+\mathrm{B}_{\mathrm{a}} \mathrm{p}_{\mathrm{b}}+\ldots+\mathrm{K}_{\mathrm{a}} \mathrm{p}_{\mathrm{k}}\right)(1+\mathrm{r})+\mathrm{wL}_{\mathrm{a}}=\mathrm{Ap}_{\mathrm{a}}
$$

The above equation can also be written as:

$$
A_{a} p_{a}(1+r)+B_{a} p_{b}(1+r)+\ldots+K_{a} p_{k}(1+r)+w_{a}=A p_{a}
$$

where $\mathrm{A}_{\mathrm{a}}, \mathrm{B}_{\mathrm{a}}, \ldots, \mathrm{K}_{\mathrm{a}}$, are the physical quantities of commodities $a, b, \ldots, k$, annually used in the production of A quantities of the commodity $a$. The corresponding prices are $\mathrm{p}_{\mathrm{a}}, \mathrm{p}_{\mathrm{b}}, \ldots, \mathrm{p}_{\mathrm{k}}$.

Each mean of production in the equation [10] was produced by other means of production and direct labour. This process can be observed in the successive rounds, which preceded the current production.

As we carry on this process, we accumulate in each date a series of direct labour quantities $\mathrm{L}_{\mathrm{at}}$, weighted by the profit factor $(1+\mathrm{r})^{\mathrm{t}}$, where $t$ represents the date or round of production of the commodity $a$ :

The price equation in terms of dated quantities of labour can be reduced into an infinite series of terms expressed as follows:

$$
\mathrm{wL}_{\mathrm{a} 0}+\mathrm{wL}_{\mathrm{a} 1}(1+\mathrm{r})+\ldots+\mathrm{wL}_{\mathrm{an}}(1+\mathrm{r})^{\mathrm{n}}+\ldots=\mathrm{Ap}_{\mathrm{a}}
$$

Except for the two distributive variables, $\mathrm{w}$ and $\mathrm{r}$, the value of all terms in the equation above are known.

One of these two distributive variables will be exogenously given, for instance the rate of profits, as Sraffa himself suggested. Therefore, we need one independent equation to determine the price of commodity $a$.

This additional equation is $\mathrm{r}=\mathrm{R}(1-\mathrm{w})$.

It will be the standard of prices and wages. Each term $\mathrm{L}_{\mathrm{at}}$ represents the quantity of direct labour used in the date $t$, in order to produce A quantities of the commodity $a$.

As we see, the above series may have infinite terms and the accuracy of the calculus will depend on the level of the rate of profits. The closer $r$ is of its maximum $\mathrm{R}$, more important will be the date $\mathrm{t}$, because the term $\mathrm{wL}_{\mathrm{at}}(1+\mathrm{r})^{\mathrm{t}}$ is a decreasing function for a rise in the profit rate, given both $L_{a t}$ and $t$ constant. In this case, we have to bring out direct labour quantities from preceding periods as far as we can.

The equation [10b] shows how complex the solution of the transformation problem of values into prices is.

Two commodities produced with the same absolute quantities of labour may have two different prices, depending on how the respective quantities of labour are distributed in time or in the successive rounds of production. Except when all the 
net income goes to wages ( $\mathrm{w}=1$ and $\mathrm{r}=0$ ), as Smith pointed out, or when the organic composition of capital expressed in value terms is identical in all industries, the prices coincide with their respective embodied labour values.

It is worth mentioning that the terms $\mathrm{L}_{\mathrm{a} 0}, \mathrm{~L}_{\mathrm{a} 1}, \ldots, \mathrm{L}_{\mathrm{an}}$, of equation [10b] are the quantities of direct and indirect labour necessary to produce " $A$ " physical quantities of commodity "a”.

Consequently, there is no logical reason to say that the Sraffa price theory is not consistent with the labour embodied theory of value.

\section{IS SRAFFA'S PRICE MODEL REALISTIC?}

Since the publication of Sraffa's book in 1960, his model received several favourable comments as well as severe critiques. The literature on the subject is vast.

As we go deeper into the generalization or realism of a model, it is natural that new challenges appear.

One of these critiques regards the problem of commensurability, since there is a physical identity between inputs and outputs in Sraffa's price equations. The same physical commodity used up as mean of production appears as output. Therefore, both input and output are commensurable. However, in the real economic world commensurability is an exception, not the rule, because production leads to transformation. In other words, during the production process inputs change physically.

As far I am concerned, the commensurability problem was raised in 2015 by two researchers, William Jefferies, from SOAS - University of London (UK) and by Christian Flamant, a French economist from the University of Paris I PanthéonSorbonne.

As a simple example, let's observe the dairy products industry.

The farmer delivers fresh milk in its primary stage to a dairy products industry. This industry transforms the milk into several by-products, like milk cream (table cream), butter, cheese, yogurt, cream cheese etc. Only a small part of the fresh milk is sold to consumers in order to fulfil their nutritional needs after a process of pasteurization. The individual price of each dairy product is higher than the price paid for the fresh milk because during the several stages of production process, value was added to these by-products, that is, different quantities of direct and indirect labour were added to the product. From a single basic commodity (milk) it is possible to produce several other products (by-products) by combining technology and labour.

A fundamental question arises. If in the real economic world commensurability is not the rule, as mentioned above, why in the price system of the classical economists, like Smith, Ricardo, Marx and more recently, Sraffa, prevails the physical commensurability between inputs and outputs?

Because it is fundamental to explain and also to determine the price of the commodities in their most basic and concise physical form. Such commodities are the primary components of the cost of production of non-basic commodities. Such 
price determination is only possible with the physical commensurability between inputs and outputs. In this sense, there is no circular reasoning in the price system proposed by both the classical economists and Sraffa.

The whole economic system can be seen as formed by two sub-systems.

The sub-system I regards the production of commodities or raw materials, which will be the inputs of the sub-system II (non-basic commodities). In sub-system I prevails the commensurability between inputs and outputs.

The assumption of commensurability is a necessary and sufficient condition for the construction of the Standard Commodity. Such that if only one commodity has a physical output different from its physical input, this invalidates the major property of the Standard Commodity, that is, for it to be an invariable measure of value.

In order to obtain a linear relationship between the wage rate and the rate of profits, inputs and outputs must be physically comparable or commensurable. Otherwise the maximum (physical) rate of profits $\mathrm{R}$ in Sraffa's model simply would not exist. Since both the determination of prices and the distribution of income depend on the Standard Commodity, any inconsistency in the construction of such a measure of value prohibits its use as an invariable standard of value.

In the sub-system II, the price of an input is treated as cost in the equations of production, since the price of each input is previously known. The price vector of sub-system I is the cost vector of sub-system II.

As the price of commodities in the sub-system $\mathrm{I}$ is the basis for the prices of sub-system II, it is necessary the determination of the maximum rate of profits $\mathrm{R}$, which is given by the technical conditions of production that prevails in the subsystem I, as well as the wage rate and the rate of profits. The level of the rate of profits could be given exogenously, as suggested by Sraffa.

\section{CONCLUSION}

The existence of a connection between the Standard Commodity and the measures proposed by Smith e Marx, is a hint that the Sraffa model could not be dissociated from the classical approach, whose basic characteristics are:

i] the economic system is a circular process, with a defined production cycle.

ii] the existence of a surplus, comprised of heterogeneous goods.

iii] the rate of profits and the wage are uniform in all production branches.

iv] the society is divided in classes.

v] the technology is given previously to price determination.

vi] the human labour is the source of value.

In my interpretation, the lack of a critical approach of the capitalist society in Production of Commodities is the main reason why Marxist economists reject the 
Sraffa's model as a substitute of the Marx's price system. Such rejection is rather ideological than logical.

I believe it is necessary to make a distinction between the figure of Sraffa as an economist, concerned with the logical rigor in the solution of specific problems unsolved by the classical economists, in particular by Ricardo, and Sraffa as a citizen. Piero Sraffa supported Antonio Gramsci and Palmiro Togliatti in different ways and occasions, probably the two major figures in the fight against the fascism in Italy during the Mussolini era.

We conclude that from a logical point of view, Sraffa's price system is superior to that of the classical economists and of Marx's. The critics of Sraffa may also state that his model does not back a dynamic analysis of the capitalist economy.

However, in macroeconomic terms, the maximum rate of profits $\mathrm{R}$, as a ratio between surplus and means of production, is equivalent to the output to capital ratio $(\mathrm{Y} / \mathrm{K})$. For instance, when the output to capital ratio of the economy as a whole is increasing, it means that the value of the net output is rising faster than the value of the means of production. In this case, we have a capital-saving technical progress, considering the daily labour journey is fixed or constant. The means of production are, therefore, being used more efficiently, with the introduction of new technologies. There is a reduction in the technical coefficients of production and therefore a reduction in the prices of commodities.

Two other important forms of technical progress are also possible: capitalusing, with $\mathrm{R}$ decreasing and neutral, when the ratio $\mathrm{R}$ is stable. The neutral technical progress has been widely used in the construction of steady growth models, especially by Harrod and Von Newmann.

When Marx formulated his law of the falling rate of profits, the capital-using technical progress or mechanisation was dominant at that time. Direct labour was being substituted by machines and the productivity increased dramatically.

However, the rise of unions, the introduction of mechanisms to preserve both the employment and the competition among industries, lead to a substitution of old machines by new ones, more efficient and cheaper. The result of this change towards a capital-saving technical progress provided a relative stability of the general rate of profits during a long period.

\section{APPENDIX I - THE STANDARD COMMODITY}

Sraffa built a composed commodity by transforming the real economic system into a new price system.

With the use of appropriate multipliers, the physical surplus of each commodity produced will be in the same proportion by which such commodity is used as mean of production.

During the elaboration of Production of Commodities by means of Commodities, Sraffa had the unavailable mathematical support from prominent mathematicians from the Cambridge University, such as Frank Plumpton Ramsey (1903-1930) and Abram Samoilovitch Besicovitch (1891-1970), as richly exposed by H. Kurz \& N. Salvadori (2000). 
The surplus or net income of this new price system, called by Sraffa as Standard Commodity, will be the measure of prices and wages of the real economic system.

Initially it is necessary to determine the $n$ multipliers $\mathrm{Q}_{1}, \mathrm{Q}_{2}, \ldots, \mathrm{Q}_{\mathrm{n}}$ and the rate of surplus $R$ (a scalar), from the $n+1$ independent equations, given below:
$\mathrm{AQ}(1+\mathrm{R})=\mathrm{BQ}$
$\mathrm{LQ}=1$

The $n$ equations of the above system [ $1 \mathrm{~A}]$ have $n+1$ unknowns. The equation [2 A] completes the set of independent equations in order to determine the multipliers $\mathrm{Q}_{\mathrm{j}}(\mathrm{j}=1,2, \ldots, \mathrm{n})$.

One of the characteristics of the Standard System is the presence of the same surplus rate $\mathrm{R}$ in all industries, calculated in physical terms, that is:

$$
\begin{aligned}
& A_{1} Q(1+R)=B_{1} Q_{1} \\
& A_{2} Q(1+R)=B_{2} Q_{2} \\
& \ldots \ldots \cdots \cdots \cdots \\
& A_{n} Q(1+R)=B_{n} Q n
\end{aligned}
$$

We shall see that the ratio $\mathrm{R}$ is determined by the conditions of production strictu sensu, regardless the distribution of income.

The respective matrices are:

$$
\mathrm{Q}=\left|\begin{array}{l}
\mathrm{Q}_{1} \\
\mathrm{Q}_{2} \\
\cdots
\end{array}\right| \begin{aligned}
& \text { Column vector of } \\
& \text { the multipliers } \mathrm{Q}_{\mathrm{j}}
\end{aligned}
$$

$\mathbf{L}=\left[\mathrm{L}_{1} \mathrm{~L}_{2} \ldots \ldots \mathrm{L}_{\mathrm{n}}\right] \quad$ Row vector of direct labour quantities

$$
\begin{aligned}
& A=\left|\begin{array}{c}
a_{11} a_{21} \ldots \ldots a_{n 1} \\
a_{12} a_{22} \ldots \ldots a_{n 2} \\
\ldots \ldots \ldots \\
a_{1 n} a_{2 n} \ldots \ldots a_{n n}
\end{array}\right| \begin{array}{l}
\text { Means of production } \\
\text { square matrix }
\end{array} \\
& A^{T}=\left|\begin{array}{c}
a_{11} a_{12} \ldots \ldots a_{1 n} \\
a_{21} a_{22} \ldots \ldots a_{2 n} \\
\ldots \ldots \ldots \\
a_{n 1} a_{n 2} \ldots \ldots a_{n n}
\end{array}\right|
\end{aligned}
$$




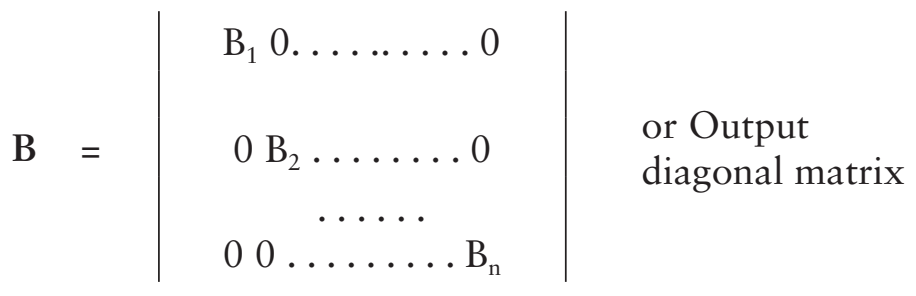

The above means of production transpose square matrix $\mathrm{A}^{\mathrm{T}}$ can also be represented by:

$$
\begin{aligned}
& \mathrm{A}_{1} \\
& \mathrm{~A}_{2} \\
\mathrm{~A}^{\mathrm{T}}= & \cdots
\end{aligned}
$$

$A_{n}$

where:

$$
\begin{aligned}
& A_{1}=\left[\begin{array}{llll}
a_{11} & a_{12} & \ldots & a_{1 n}
\end{array}\right] \\
& A_{2}=\left[\begin{array}{llll}
a_{21} & a_{22} & \ldots & a_{2 n}
\end{array}\right]
\end{aligned}
$$$$
\text { An }=\left[a_{n 1} a_{n 2} \ldots a_{n n}\right] \backslash
$$

Each $\mathbf{A}_{j}$ for $\mathbf{j}=1,2, \ldots, n$; represents the inputs of commodity $j$ used as mean of production in the several industries.

$$
\mathrm{p}=\left[\mathrm{p}_{1} \mathrm{p}_{2} \ldots \ldots \mathrm{p}_{\mathrm{n}}\right] \text { Row vector of prices of production }
$$

The rate $\mathrm{R}$ is analogue to that imagined by Ricardo in his Essay on Profits, written in February 1815, as a ratio of two quantities physically homogeneous (corn-corn model), so that the quotient obtained between profits and means of production is a pure number.

As a result, the Standard System is therefore represented by:

$$
\mathrm{pAQ}(1+\mathrm{r})+\mathrm{LQw}=\mathrm{pBQ}
$$

Let's see in detail the construction of the Standard Commodity.

In both the original price system as in the Standard System, the wages should be distributed in each industry according to the respective quantities of direct labour.

Ence the necessity of the identity $L Q=1$.

Such condition is fundamental to understand the concept of Sraffa's Standard Commodity as well as the distribution of the net income between wages and profits according to the labour theory of value in Sraffa's model.

From the system [3 A] we obtain the net income or surplus, which is divided between wages and profits: 


$$
\mathrm{rpAQ}+\mathrm{wLQ}=\mathrm{p}(\mathbf{B}-\mathbf{A}) \mathrm{Q}
$$

When $\mathrm{w}=0$, the rate of profits $(\mathrm{r})$ is maximum and identical to $\mathrm{R}$.

Therefore, the system [3 A.1] can be expressed as follows:

$$
\mathrm{pAQR}=\mathrm{p}(\mathrm{B}-\mathrm{A}) \mathrm{Q}
$$

On the other hand, the maximum rate of profits $\mathrm{R}$ can also be written as:

$$
(1+\mathrm{R}) \mathrm{AQ}=\mathrm{Q}
$$

In order to determine the maximum rate of profits in the Standard System, we have to multiply all elements of both sides of the above equation [4] by a column vector I (one row and $n$ columns with all elements equal to 1 ).

$$
\mathrm{R}=[\mathrm{IQ}-\mathrm{IAQ}] / \mathrm{IAQ}
$$

In other words, the maximum rate of profits in the Standard System is identical to the rate of surplus R expressed in physical terms, similar to David Ricardo's corn model in his Essay on Profits.

Our next step is to demonstrate how we can obtain a linear relationship between wages and profits which attends the mathematical condition above.

The value of the National Income or surplus must be exactly equal to the whole quantity of direct labour dispended in the production period, that is:

$$
\mathbf{p}(\mathbf{B}-\mathbf{A}) \mathrm{Q}=\mathrm{LQ}
$$

Besides, Sraffa adopted the value of the Standard Commodity as the unit of measure of prices and wage, that is:

$$
\mathbf{p}(\mathrm{B}-\mathrm{A}) \mathrm{Q}=1
$$

Going back to the system [3 A 1], it does not change if we multiply all terms by the scalar R:

$$
\mathrm{rpAQR}+\mathrm{LQwR}=\mathrm{p}(\mathrm{B}-\mathrm{A}) \mathrm{QR}
$$

Combining [2 A], [3 A 2] and [6 A], we finally obtain:

$$
\begin{aligned}
& r+w R=R \\
& r=R(1-w)
\end{aligned}
$$

Now we have a crystal-clear relationship between the rate of profits and the wage rate.

As we can see, both prices and quantities were isolated and the logical inconsistency observed in the Marxian price system was completely eliminated.

The level of efficiency of the economic system is given by the maximum rate of profits R. For example, the higher the level of R, the lower will be the quantity of means of production necessary to produce the same quantity of commodities. 


\section{APPENDIX II - TECHNICAL PROGRESS AND INCOME DISTRIBUTION}

Let's see how technical progress affects the distribution of income in a very simplified situation.

In this general numerical example, there are only two industries and two periods of production.

The prevailing technical progress could be of three types, as follow:

- Capital-saving: there is a decrease in the quantity of inputs or in the coefficients of production $\left(\mathrm{a}_{\mathrm{ij}}\right)$ in order to produce one unity of commodity $i$ (i $=1,2, \ldots, \mathrm{n})$. The output to capital $(\mathrm{Y} / \mathrm{K})$ increases.

- Capital-using: there is an increase in the quantity of inputs or in the coefficients of production $\left(\mathrm{a}_{\mathrm{ij}}\right)$ in order to produce one unity of commodity $i$ (i $=1,2, \ldots, \mathrm{n})$. The output to capital ratio $(\mathrm{Y} / \mathrm{K})$ decreases.

- Neutral: there is no change in the coefficients of production from a period to other. The output to capital ratio $(\mathrm{Y} / \mathrm{K})$ keeps flat.

Two other forms of technical progress, labour-using and labour-saving techniques are not discussed in our numerical example at this stage.

The first Brazilian economist to analyse exhaustively the three above classical forms of technical progress from the labour theory of value standpoint and their impact on income distribution in the long run was Luiz Carlos Bresser-Pereira (1988). The essay Distribuição de renda e o modelo clássico (Income distribution and the classical model, 2004, see References) provides an analysis of the work of Bresser-Pereira and its relation with Sraffa's model.

The general price equations at end of Period I:

$\left(50 \mathrm{p}_{1}+30 \mathrm{p}_{2}\right)(1+\mathrm{r})+50 \mathrm{w}=100 \mathrm{p}_{1}$

$\left(30 \mathrm{p}_{1}+20 \mathrm{p}_{2}\right)(1+\mathrm{r})+30 \mathrm{w}=70 \mathrm{p}_{2}$

The first industry needs 50 tons of commodity 1 and 30 tons of commodity 2 plus 50 units of direct labour to produce 100 tons of commodity 1 .

The second industry needs 30 tons of commodity 1 and 20 tons of commodity 2 plus 30 units of direct labour to produce 70 tons of commodity 1 .

The surplus is given by:

$20 \mathrm{p}_{1}+20 \mathrm{p}_{2}$

The two above general price equations can be transformed into Sraffa's price equations:

$\left[(50 / 100) \mathrm{p}_{1}+(30 / 70) \mathrm{p}_{2}\right](1+\mathrm{r})+(50 / 80) \mathrm{w}=(100 / 100) \mathrm{p}_{1}$

$\left[(30 / 100) \mathrm{p}_{1}+(20 / 70) \mathrm{p}_{2}\right](1+\mathrm{r})+(30 / 80) \mathrm{w}=(70 / 70) \mathrm{p}_{2}$

which can be reduced to

$\left[0.5 \mathrm{p}_{1}+(3 / 7) \mathrm{p}_{2}\right](1+\mathrm{r})+(5 / 8) \mathrm{w}=\mathrm{p}_{1}$

$\left[0.3 \mathrm{p}_{1}+(2 / 7) \mathrm{p}_{2}\right](1+\mathrm{r})+(3 / 8) \mathrm{w}=\mathrm{p}_{2}$

Surplus: $(20 / 100) \mathrm{p}_{1}+(20 / 70) \mathrm{p}_{2}$ 
Note that the each of direct quantity of labour was divided by 80 , the sum of $\mathrm{L}_{1}$ with $\mathrm{L}_{2}$.

With the general formulas on Appendix I, we obtain the following results:

$\mathrm{Q}_{1}=1.042901$

$\mathrm{Q}_{2}=0.928498$

$\mathrm{R}=0.303626$ or $30.3626 \%$

Let's suppose the wage rate is 0.5

$\mathrm{p}_{1}=2.652030$

$\mathrm{p}_{2}=1.645365$

$\mathrm{r}=0.151815$ or $15.1815 \%$

Net income (Y): 1.000510

Capital (K): 3.296885

Therefore, the output to capital ratio $\mathrm{Y} / \mathrm{K}=0.303471$

Total profits $(\mathrm{P})=0.500510$

Total wages $(\mathrm{W})=0.500000$

In the next period, the entrepreneur of industry 1 uses a new technique, which reduces losses of raw materials during the production process. The quantity of commodity 1 necessary to produce 100 tons of commodity 1 was reduced in $10 \%$, from 50 tons to 45 tons.

This is a capital-saving technique.

Therefore, the new price equations in Period II are given below:

$\left(45 \mathrm{p}_{1}+30 \mathrm{p}_{2}\right)(1+\mathrm{r})+50 \mathrm{w}=100 \mathrm{p}_{1}$

$\left(30 \mathrm{p}_{1}+20 \mathrm{p}_{2}\right)(1+\mathrm{r})+30 \mathrm{w}=70 \mathrm{p}_{2}$

Now the first industry needs 45 tons of commodity 1 and 30 tons of commodity 2 plus 50 units of direct labour in order to produce 100 tons of commodity 1 .

The second industry needs 30 tons of commodity 1 and 20 tons of commodity 2 plus 30 units of direct labour to produce 70 tons of commodity 1 .

The surplus or Net Income is given by:

$25 \mathrm{p}_{1}+20 \mathrm{p}_{2}$

The two above general price equations transformed into Sraffa's price equations:

$\left[0.45 \mathrm{p}_{1}+(3 / 7) \mathrm{p}_{2}\right](1+\mathrm{r})+(5 / 8) \mathrm{w}=\mathrm{p}_{1}$

$\left[0.30 \mathrm{p}_{1}+(2 / 7) \mathrm{p}_{2}\right](1+\mathrm{r})+(3 / 8) \mathrm{w}=\mathrm{p}_{2}$

Surplus: $(25 / 100) \mathrm{p}_{1}+(20 / 70) \mathrm{p}_{2}$

$\mathrm{Q}_{1}=1.018182$

$\mathrm{Q}_{2}=0.969697$

$\mathrm{R}=0.359223$ or $35.9223 \%$

Let's suppose again that the wage rate is 0.5 . The labourers kept the same share in the National Income. 
$\mathrm{p}_{1}=2.285161$

$\mathrm{p}_{2}=1.502608$

$\mathrm{r}=0.179612$ or $17.9612 \%$

Net income (Y): 1.000607

Capital (K): 2.787162

Therefore, the output to capital ratio $\mathrm{Y} / \mathrm{K}=0.359006$

Total profits $(\mathrm{P})=0.500607$

Total wages $(\mathrm{W})=0.500000$

Which are the major conclusions when we compare the two periods above?

The new technique in industry 1 is more efficient than the previous one, because the surplus in such industry rose from 20 tons to 25 tons with the same quantity of inputs.

As we saw on Appendix I, the determination of the ratio R depends on both the physical quantities of commodities and direct labour. If there is no physical surplus, $\mathrm{R}$ will be null.

In the Period 2 the Standard ratio rose from $30.36 \%$ to $35.92 \%$, which explains the rise in the value of net income in relation to the value of means of production.

The output to capital ratio, $\mathrm{Y} / \mathrm{K}$, also rose from 0.303 to 0.359 , since the capital-saving technique in industry 1 on the one side provided a significant increase in the net income and on the other reduced the value of the capital employed in the production of commodity 1 .

Regarding the capital-using technique, the conclusions will be the opposite of the capital-saving. If the capital-using technique leads to a decrease in the Standard ratio $R$, why such technique is adopted in some industries?

In my humble opinion, it is because the entrepreneurs in order to increase the market-share of their products are more interested to increase the sum of profits even with a fall of the rate of profits. Of course, not below a minimum level that does not offset the business risk.

When we observe long term statistical figures regarding the evolution of monetary aggregates of income, wages, profits, the number of hours of direct labour dispended in each period of time and the value of the stock of capital, the three types of technical progress above commented appear alternatively as dominant. However, such changes from one to other form of technical progress may demand a time relatively long to be noted and classified as dominant.

There is a long discussion in the economic literature about the choice of techniques since Nobuo Okishio (1927-2003), emeritus professor at Kobe University in Japan, published in 1961 his famous paper "Technical Changes and the Rate of Profit”, Kobe University Economic Review vol. 7, pp. 85-99. 


\section{APPENDIX III - RENT AND INTEREST}

Let's suppose the industrial plants of both industries are located in the properties of third parties and the entrepreneurs pay an annual rent for the rentiers or owners of such real estate properties.

We suppose that both the entrepreneurs and the rentiers signed a long-term contract for the use of the real estate properties. The contract is important to avoid future demands from both sides regarding eventual oscillations in the economic cycle, which may affect the level of the money interest rate, for instance.

The price the rentier charges for the use of his land is the money rate of interest (i), the same we referred to above.

This annual rent $C_{j}$ is a fixed cost for entrepreneur and it is given by the following relation

$$
\begin{aligned}
& \mathrm{C}_{1}=\mathrm{i} \lambda_{1} \\
& \mathrm{C}_{2}=\mathrm{i} \lambda_{2}
\end{aligned}
$$

where $\lambda_{j}(j=1,2)$ can be interpreted as the quantity of the real state property adjusted per unit of commodity $\mathrm{j}$ produced.

The annual rent is paid by the entrepreneur to the rentier at the end to the production period and it is a deduction of gross profits in each industry.

$\mathrm{r}\left(\mathrm{a}_{11} \mathrm{p}_{1}+\mathrm{a}_{21} \mathrm{p}_{2}\right)-\mathrm{C}_{1}=$ remaining profits after the deduction of rent in industry 1

$r\left(a_{12} p_{1}+a_{22} p_{2}\right)-C_{2}=$ remaining profits after the deduction of rent in industry 2

Therefore, in this case the effective rate of profits for the entrepreneurs will be lower than that obtained by the relation $r=i+\sigma$ or by $r=R(1-w)$ and it depends on the magnitude of $\mathrm{C}_{\mathrm{j}}$.

The rent paid to owners of land and real estate properties is a complex question in any country and particularly in some countries where land and real estate properties for residential, commercial and industrial purposes in large cities are highly concentrated in the hands of few people or families due to historical reasons. The rent requested by the owner in several cases is so high that any business cannot thrive for a long time. This situation explains partially the high cost of living in the majority of large cities in some countries.

As far I am concerned, in some countries of Europe such question was partially resolved many decades ago by the government through a higher taxation on personal income or on the value of land and real estate properties. Great part of the additional taxation is reverted to companies and families that pay a high rent.

Likewise, the amount of interest paid by the entrepreneur on loans from banks to finance his business must be treated as a deduction of gross profits in Sraffa's price system. 


\section{REFERENCES}

Anderaos de Araujo, Fabio (1982) "Preços e distribuição do valor segundo Sraffa", Revista de Economia Política, Vol. 2, No.3, pp. 107-132.

Anderaos de Araujo, Fabio (1984) "Progresso técnico e distribuição de renda", Revista de Economia Politica, Vol. 14, No.1, pp. 147-157.

Anderaos de Araujo, Fabio (1985) “Preços e distribuição em Sraffa: uma reconsideração” Pesquisa \& Planejamento Econômico, Vol. 15, No.3, pp. 457-461.

Anderaos de Araujo, Fabio (2004) “Distribuição de renda e o modelo clássico”, Em busca do novo: O Brasil e o desenvolvimento na obra de Bresser-Pereira, Yoshiaki Nakano, José Marcio Rego, Lilian Furquim (org), Editora FGV, São Paulo, Brasil, pp. 201-213. The English version of this essay is available for download by accessing Academia.edu website.

Benetti, Carlo (1978) Valor e Repartição, Coimbra, Portugal: Editorial Centelha.

Bresser-Pereira, Luiz Carlos (1988) Lucro, Acumulação e Crise (Profit, Accumulation and Crisis), $2^{\text {nd }}$ edition, São Paulo: Brasiliense.

Flamant, Christian (2015) "Commodities do not produce commodities: a critical review of Sraffa's theory of production and prices". Real-World Economics Review, n 72, pp. 118-133.

Garegnani, Pierangelo (1984) "Value and distribution in the classical economists and Marx", Oxford Economic Papers, Vol. 36, pp. 291-325.

Hoffmann, Rodolfo (2013) Produtividade e Preços em Sistemas Sraffianos, São Paulo: LP Books.

Jefferies, William (2015) "Piero Sraffa and the production of commodities by means of magic", research-article, Critical Sociology, 16 p. (Feb 17, 2015).

Kurz, Heinz \& Salvadori, Neri (2000) "Sraffa and the mathematicians: Frank Ramsey and Alister Watson”, In Piero Sraffa’s Political Economy - A Centenary Estimate - Terenzio Cozzi \& Roberto Marchionatti, UK: Routledge.

Lippi, Marco (1998) "The standard commodity”, The Elgar Companion to Classical Economics, Heinz Kurz \& Neri Salvadori (ed), Aldershot \& Lyme, Edward Elgar, pp. 410-415.

Mario Nuti, Domenico (1981) Economic Essays on Value, Competition and Utility, Cambridge: Cambridge University Press.

Marx, Karl (1972) “Capital” vol. III, Lawrence \& Wishart.

May, Kenneth (1948) "Values and price of production: A note on Winternitz solution", The Economic Journal, Vol. 58, pp. 596-599.

Meek, Ronald Lindley (1956) "Some notes on the transformation problem", The Economic Journal, Vol. 66, pp. 94-107.

Mongiovi, Gary (2016) “Sraffa, capitalist production and labour values: a comment”, Critical Sociology, 13 pp (October 19).

Naldi, Nerio (2012) "Keynes and Sraffa on the concept of commodity rate of interest", Speculation and regulation in commodity markets: the Keynesian approach in theory and practice, Maria Cristina Marcuzzo (ed), Universitá di Roma La Sapienza.

Napoleoni, Claudio (1973) A Teoria Econômica no Século XX. Portugal: Editorial Presença.

Napoleoni, Claudio (1980) O Valor na Ciência Econômica. Portugal: Editorial Presença.

Perri, Stefano (2014) "The standard system and the tendency of the (Maximum) rate of profits to fall - Marx and Sraffa: there and back", in Towards a New Understanding of Sraffa: Insights from Archival Research, R. Bellofiore \& S Carter (ed), Palgrave Macmillan, pp 94-120.

Ricardo, David (1951) “On the principles of political economy and taxation”, The Works and Correspondence of David Ricardo, Vol. I, Piero Sraffa (ed), Cambridge: Cambridge University Press.

Roncaglia, Alessandro (1978) Sraffa and the Theory of Prices. London: John Wiley \& Sons.

Seton, Francis (1957) “The transformation problem”, Review of Economic Studies, Vol. 24, pp. 149160. 
Smith, Adam (1965) "An inquiry into the nature and causes of the Wealth of Nations", $5^{\text {th }}$ edition, 1789, Edward Cannan (ed), The Modern Library, New York: Random House.

Sraffa, Piero (1960) Production of Commodities by Means of Commodities - Prelude to a Critic of Economic Theory, Cambridge: Cambridge University Press.

Winternitz, Joseph (1948) "Values and prices - a solution of the so-called transformation problem", The Economic Journal, Vol. 58, No. 230, pp. 276-280. 